\title{
Wyznaczanie wielkości krytycznych odporności na pękanie stali i złączy spawanych
}

\author{
Determination of the critical values of toughness on crack \\ of steels and welded joints
}

\section{Streszczenie}

W pracy przedstawiono wyniki badań różnych gatunków stali i ich złączy spawanych oraz wzory (równania), które zastosowano do wyznaczenia wielkości krytycznych dla kryteriów odporności na pękanie. Dotyczą one zarówno zakresu liniowo-sprężystej, jak i sprężysto-plastycznej mechaniki pękania. Ponadto porównano eksperymentalnie wyznaczone rozwarcie czoła pęknięcia (CTOD) z wartościami obliczonymi według proponowanej w literaturze zależności, określającej jego korelację z wynikami badań udarności stali i złączy spawanych. Oceniono zgodność odporności na pękanie z użyciem dostępnych i znanych równań.

Słowa kluczowe: pękanie; złącze spawane; wielkości krytyczne odporności na pękanie; CTOD 
elementów skończonych, jak opisano to dla złącza krzyżowego w pracy [6].

W przypadku elementów stalowych o małej grubości (mniejszych od ok. $10 \mathrm{~mm}$ ) przy wyższym poziomie naprężenia $\left(S_{r}>0,5\right)$ na czole szczeliny pojawia się duża strefa odkształcenia plastycznego. Zgodnie z założeniami sprężysto-plastycznej mechaniki pękania (SPMP) [1 $\div 4]$ kryterium pękania powinno uwzględniać w tych warunkach odkształcenie plastyczne na czole szczeliny. 0 możliwości nagłego pękania decyduje wielkość rozwarcia czoła szczeliny $\delta$ [2:4], która po osiągnięciu wartości krytycznej $\delta_{c}$ powoduje nagłe pękanie elementu. Wyraża się to następującą zależnością:

$$
\delta=\delta_{c} \text {. }
$$

Innym kryterium w zakresie SPMP jest całka J wyznaczana jako wielkość energii wymaganej do rozwoju pęknięcia. Według tego kryterium nagły rozwój pęknięcia w materiale wystąpi wtedy gdy całka J osiągnie wartość krytyczną $J_{c}(3)$ :

$$
\left(J=J_{c}\right) \text {. }
$$

Jednak w niskich temperaturach, zwykle w temperaturach poniżej $-20^{\circ} \mathrm{C}$, znacznie wzrasta kruchość stali. Sygnalizuje ją prawie w 100\% krystaliczny przełom próbek przeznaczonych do pomiaru udarności. Można wtedy stosować kryterium LSMP (również przy wyższym zakresie naprężenia $\left.0,5<\mathrm{S}_{\mathrm{r}} \leq 0,8\right)$ zamiast kryteriów SPMP.

Wyznaczanie wielkości krytycznych: odporności na pękanie $\mathrm{K}_{\mathrm{lc}}$, rozwarcia czoła pęknięcia $\delta_{\mathrm{lc}}$ (ang. crack tip opening displacement - CTOD) albo całki $J_{\mathrm{Ic}} \mathrm{wg}$ I modelu wzrostu

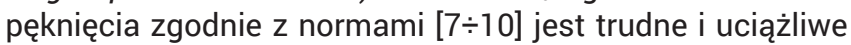
oraz wymaga odpowiedniego wyposażenia laboratorium. Trudności te wynikają ze sposobu wykonania i przygotowania próbek do badań oraz konieczności zachowania odpowiednich warunków i procedury badań [10]. Z tego powodu ciągle poszukuje się zależności, wiążących wyniki standardowych badań właściwości mechanicznych materiału z wartościami krytycznymi parametrów odporności na pękanie. Są to najczęściej zależności łączące wyniki pracy udarowego zginania próbek z karbem ostrym Charpy V - KV (wyrażonej w J) z wartościami krytycznymi $\mathrm{K}_{\mathrm{lc}} \mathrm{i} \delta_{\mathrm{lc}}$, co przedstawiono w pracy [4]. Można spotkać także prace omawiające inne metody określania tych wielkości, np. wyznaczenie wartości $K_{\mathrm{lc}}$ dla powłok natryskiwanych plazmowo na podstawie pomiaru długości spękań wokół odcisku powstałego przy pomiarze twardości metodą Vickersa [11]. Takie alternatywne podejścia do określenia parametrów odporności materiału na pękanie są z reguły możliwe do zastosowania w warunkach laboratoriów jakimi dysponuje przemysł.

\section{Krytyczne parametry odporności materiału na pękanie}

\section{Zależności korelacyjne określające parametry krytyczne mechaniki pękania}

Na podstawie pracy udarowego łamania KV próbek typu "Charpy V" (wyznaczonej w J) można określić odporność na pękanie $\mathrm{K}_{\mathrm{Ic}}$ (wyrażoną w MPa $/ \mathrm{m}$ ) z następujących zależności korelacyjnych [4]:

$$
\begin{aligned}
& \mathrm{K}_{\mathrm{lc}}=\sqrt{0,00022 \cdot \mathrm{E} \cdot(\mathrm{KV})^{3 / 2},}, \\
& \mathrm{~K}_{\mathrm{lc}}=\sqrt{0,00137 \cdot \mathrm{E} \cdot(\mathrm{KV}),} \\
& \mathrm{K}_{\mathrm{lc}}=14,5 \sqrt{(\mathrm{KV})}, \\
& \mathrm{K}_{\mathrm{lc}}=0,53(\mathrm{KV})+57,9 .
\end{aligned}
$$

Natomiast krytyczną wartość rozwarcia czoła pęknięcia - CTOD (wyrażoną w mm) można określić wzorem korelacyjnym (8), jak wykazano to $w$ pracy [12]:

$$
\mathrm{CTOD}=\delta_{\mathrm{c}}=0,0024 \cdot \mathrm{KV}
$$

\section{Wyniki badań i obliczeń wartości krytycznych $\mathrm{K}_{\mathrm{Ic}}$ i CTOD}

Badania podstawowych właściwości mechanicznych, tj. granicy plastyczności $R_{e}$, wytrzymałości na rozciąganie $R_{m}$ i pracy udarowego zginania KV przeprowadzono dla spoin złączy spawanych wykonanych z blachy o grubości $40 \mathrm{~mm}$ ze stali YP355. Zastosowano materiał dodatkowy $\mathrm{w}$ formie drutu proszkowego do spawania łukowego o średnicy 1,2 mm zgodnego z normą EN ISO 17632-A: T 464 ZP M 2 H5 o nazwie handlowej SF-3AM $\left(R_{e}=550 \mathrm{MPa}, R_{m}=590 \mathrm{MPa}\right.$, $\left.R_{e} / R_{m}=0,932, A_{5}=29 \%, K V-40{ }^{\circ} \mathrm{C}=128 \mathrm{~J}\right)$. Spoiny złączy spawanych dwustronnie (ukosowanie $\mathrm{X}$ ) wykonano metodą MAG w osłonie mieszanki gazowej M21 $\left(\mathrm{Ar}+\mathrm{CO}_{2}\right)$ wg PN-EN ISO 14175. Wyznaczono eksperymentalnie na próbkach zginanych, zgodnie z normą [9], krytyczne wartości rozwarcia czoła pęknięcia $\delta_{c}$ (CTOD) w spoinie. Badania krytycznej wartości rozwarcia pęknięcia CTOD i pracy udarowego zginania KV oraz podstawowych właściwości mechanicznych materiału spoiny przeprowadzono $w$ temperaturze $\mathrm{t}=-60^{\circ} \mathrm{C}$. Wartości średnie wyników badań $w$ tej temperaturze oraz obliczeń CTOD wg wzoru (8) zestawiono w tablicy I.

Na podstawie wyników badań i obliczeń określono błąd względny B - czyli różnicę między wartością CTOD obliczo-

\begin{tabular}{|c|c|c|c|c|c|c|c|}
\hline $\mathbf{R}_{\mathrm{e}}$ [MPa] & $\mathbf{R}_{\mathrm{m}}[\mathrm{MPa}]$ & $R_{e} / R_{m}[-]$ & KV [J] & CTOD $_{\text {exp. }}[\mathrm{mm}]$ & $\mathrm{CTOD}_{\mathrm{wz} .(8)}[\mathrm{mm}]$ & Błąd B [\%] & $\mathrm{W}=\frac{\mathrm{CTOD}_{\mathrm{wz} .(8)}}{\mathrm{CTOD}_{\text {exp. }}}$ \\
\hline 545 & 601 & 0,907 & 130 & 0,48 & 0,31 & -35 & 0,65 \\
\hline 545 & 601 & 0,907 & 62 & 0,45 & 0,15 & -67 & 0,33 \\
\hline 601 & 646 & 0,930 & 102 & 1,02 & 0,25 & -76 & 0,24 \\
\hline 601 & 646 & 0,930 & 77 & 0,95 & 0,18 & -81 & 0,19 \\
\hline 665 & 699 & 0,951 & 93 & 1,34 & 0,22 & -83 & 0,17 \\
\hline 665 & 699 & 0,951 & 107 & 1,39 & 0,26 & -81 & 0,19 \\
\hline
\end{tabular}
ną ze wzoru (8) a jej wynikiem wyznaczonym eksperymentalnie, odniesioną do tego wyniku (tabl. I):

$$
\mathrm{B}=\frac{\mathrm{CTOD}_{\mathrm{wz} .(8)}-\mathrm{CTOD}_{\text {exp. }}}{\mathrm{CTOD}_{\text {exp. }}} \cdot 100 \%
$$

Tablica I. Właściwości mechaniczne spoin złączy wykonanych przy użyciu drutu SF-3AM, $t=-60{ }^{\circ} \mathrm{C}$ Table I. Mechanical proprieties of weld material of joints made using the wire SF-3AM, $t=-60^{\circ} \mathrm{C}$ 
Przedstawione w tablicy I wyniki CTOD obliczone wg wzoru (8) różnią się dość znacznie od wyników wyznaczonych eksperymentalnie, zwłaszcza przy wysokich wartościach granicy plastyczności - bliskich wytrzymałości na rozciąganie (np. dla $R_{e} / R_{m}=0,951|B|>80 \%$ ). Należy też zauważyć, że wielkość rozwarcia pęknięcia wyznaczona doświadczalnie rośnie szybko i prawie liniowo wraz ze wzrostem wartości $R_{e} / R_{m}$ (rys. 1), podczas gdy wartość tego parametru obliczona ze wzoru (8) na podstawie pracy udarowego zginania KV jest w przybliżeniu niemal stała.

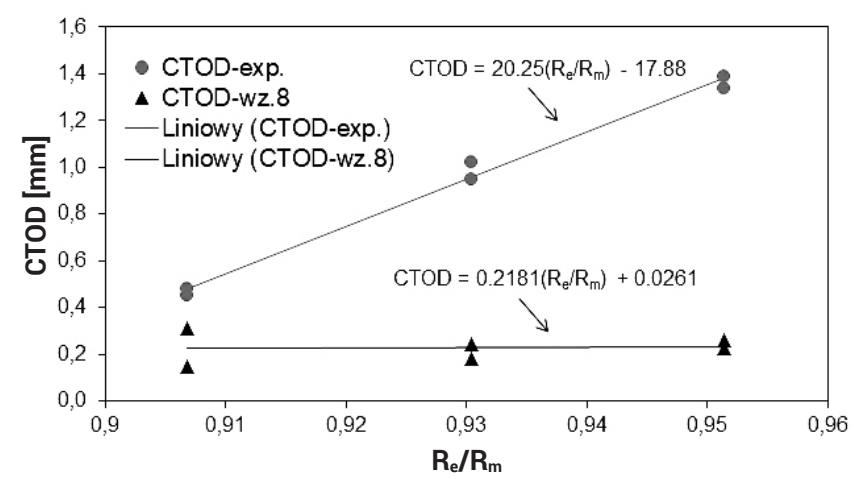

Rys. 1. Krytyczna wartość rozwarcia czoła pęknięcia w spoinie złączy wykonanych przy użyciu drutu SF-3AM

Fig. 1. Critical value of crack tip opening displacement in weld material of joints made using the wire SF-3AM

Według liniowych zależności określających zmianę wielkości CTOD (rys. 1) zbliżone wartości wyników obliczeniowych i eksperymentalnych rozwarcia czoła pęknięcia uzyskano by po ekstrapolacji tych zależności do wartości $R_{e} / R_{m}$

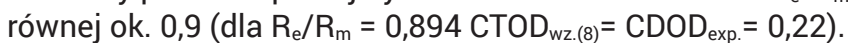

Aby uzyskać zbliżone wartości CTOD ze wzoru (8) do wyników eksperymentu należałoby wprowadzić do niego współczynnik poprawkowy (korekcyjny) W, dla badanego zakresu wartości $R_{e} / R_{m}$, który określono jako:

$$
W=\frac{C T O D_{\text {wz.(8) }}}{\text { CTOD }_{\text {exp. }}} \text {. }
$$

Wtedy rzeczywistą wartość rozwarcia czoła pęknięcia CTOD $_{\text {rzecz. }}$ można opisać zależnością:

$$
\mathrm{CTOD}_{\text {rzecz. }}=\mathrm{CTOD}_{\text {exp. }}=\mathrm{W} \cdot \mathrm{CTOD}_{\mathrm{wz} .(8)} \text {. }
$$

Wielkość współczynnika W można wyznaczyć za pomocą kwadratowej funkcji aproksymującej wyniki określone wzorem (10), co przedstawiono na rysunku 2.

Omówioną wyżej rozbieżność między wynikami CTOD obliczonymi wg wzoru (8) a wynikami uzyskanymi eksperymentalnie można tłumaczyć tym, że empiryczny wzór (8) został określony dla typowych stali konstrukcyjnych - tj. materiałów o modelu sprężysto-plastycznym z umocnieniem

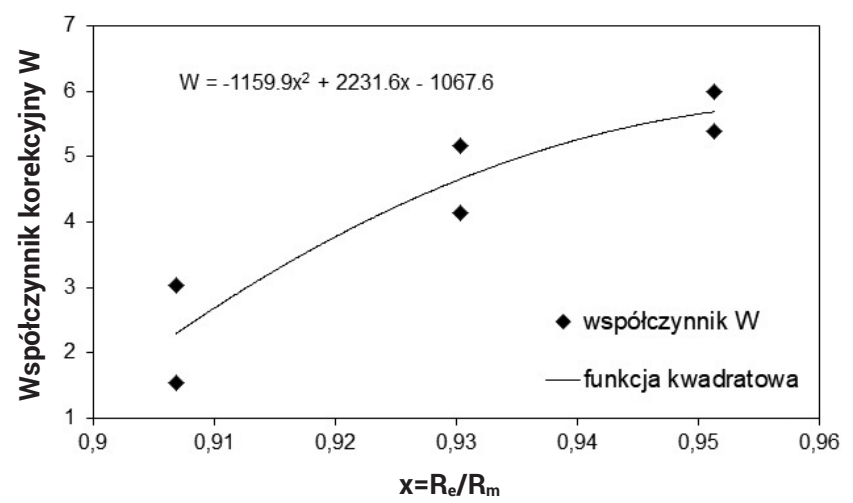

Rys. 2. Zmiana wartości współczynnika korekcyjnego W wg wzoru (10) dla materiału spoin wykonanych przy użyciu drutu SF-3AM Fig. 2. Change of value of the corrective coefficient $W$ according to example (10) for material welds made using the wire SF-3AM (rys. 3a). Stale kwalifikowane do tego modelu charakteryzują się wyraźnie niższą granicą plastyczności w porównaniu $z$ wytrzymałością na rozciąganie $\left(R_{e} / R_{m}<0,9\right)$. Spiętrzone naprężenie na czole szczeliny przekraczające granicę plastyczności takiego materiału powoduje jego umocnienie, to jest wzrost poziomu naprężenia potrzebnego do dalszego odkształcenia plastycznego - umożliwiającego plastyczny wzrost szczeliny. W związku z tym o nagłym rozwoju pęknięcia będzie w dużym stopniu decydować kruchość materiału, a nie jego plastyczność. Dlatego krytyczne rozwarcie pęknięcia w takim materiale będzie niewielkie, a jego wartość CTOD można z niewielkim błędem obliczyć ze wzoru (8).

Natomiast $w$ materiale o poziomie $R_{e}$ bliskim $R_{m}$ $\left(R_{e} / R_{m}>0,9\right)$, tj. w materiale o znacznej ciągliwości - zbliżonym do modelu sprężysto-plastycznego bez umocnienia (rys. 3b), spiętrzone naprężenie na czole szczeliny po przekroczeniu granicy plastyczności spowoduje utworzenie dużej strefy plastycznej o znacznym odkształceniu. W wyniku tego wzrośnie wartość krytyczna CTOD w porównaniu do materiału o charakterystyce zbliżonej do modelu sprężysto-plastycznego z umocnieniem. Wzrost ten może wystąpić nawet w warunkach niskich temperatur, jak w omówionym przypadku zastosowanego materiału dodatkowego do spawania. Wynikać to może z faktu, że oprócz kruchego pękania, wystąpi też pękanie plastyczne (ciągliwe), co potwierdza wysoki poziom pracy udarowego łamania próbek KV badanego materiału w niskich temperaturach. Nie uwzględnia tego wzór (8) i dlatego wyniki obliczeń CTOD wg tego wzoru będą znacznie zaniżone (ujemne wartości błędów) w porównaniu z wynikami eksperymentu.

a)

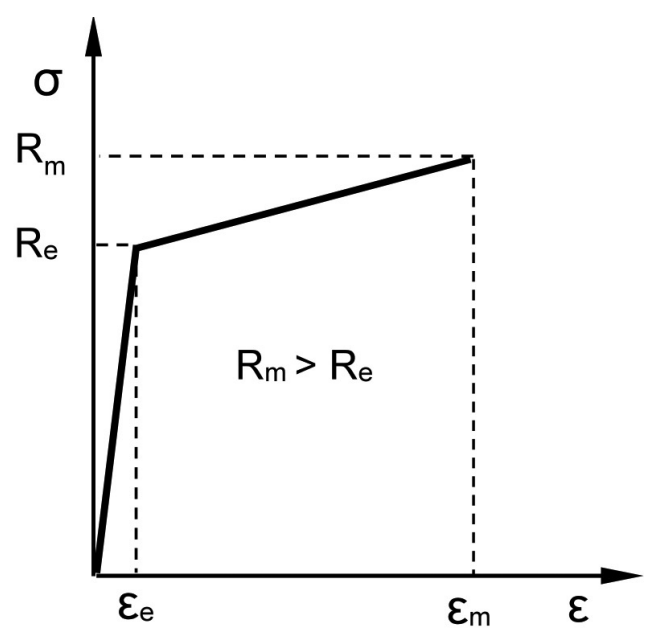

b)

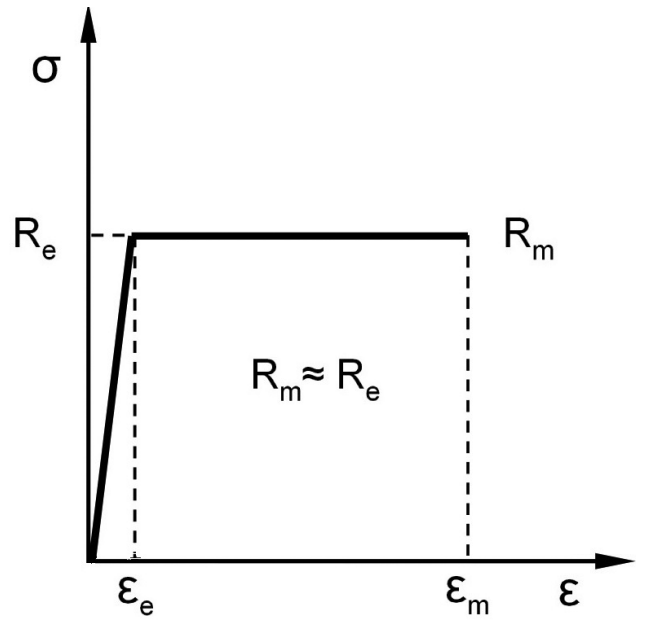

Rys. 3. Modele materiału ze względu na właściwości mechaniczne: a) materiał sprężysto-plastyczny z umocnieniem, b) sprężysto - idealnie-plastyczny (bez umocnienia)

Fig. 3. Models of the material because of mechanical proprieties: a) the elastic-plastic material with strengthen, b) the elastic - ideally-plastic material (without the strengthen) 
Tablica II. Właściwości mechaniczne spoin wykonanych przy użyciu drutu SF-3AM $\left(\mathrm{t}=-36^{\circ} \mathrm{C}\right)$

Table II. Mechanical proprieties of weld material of joints made using the wire SF-3AM $\left(t=-36^{\circ} \mathrm{C}\right)$

\begin{tabular}{|c|c|c|c|c|c|c|}
\hline$R_{e}[\mathrm{MPa}]$ & $\mathbf{R}_{\mathrm{m}}[\mathrm{MPa}]$ & $\mathbf{R}_{\mathrm{e}} / \mathbf{R}_{\mathrm{m}}[-]$ & KV [J] & $\mathrm{CTOD}_{\text {exp. }}[\mathrm{mm}]$ & $\mathrm{CTOD}_{\mathrm{wz} .(8)}[\mathrm{mm}]$ & Błąd B [\%] \\
\hline 545 & 602 & 0,905 & 78,7 & 0,27 & 0,19 & -30 \\
\hline 550 & 609 & 0,903 & 115,3 & 0,36 & 0,28 & -22 \\
\hline 552 & 580 & 0,952 & 101,7 & 0,66 & 0,24 & -64 \\
\hline
\end{tabular}

Reasumując można powiedzieć, że praca udarowego zginania próbek odzwierciedla w materiale o małym stosunku $\mathrm{R}_{\mathrm{e}} / \mathrm{R}_{\mathrm{m}}$ głównie niewielką pracę końcowego zniszczenia próbek poprzez kruche pękanie. Natomiast w materiale o dużej wartości $R_{e} / R_{m}$ odzwierciedla też w znacznym stopniu pracę pękania ciągliwego, co powoduje zwiększenie błędów obliczeń wartości CTOD wg wzoru (8).

Podobnie małe wartości obliczeń CTOD wg wzoru (8), wyraźnie mniejsze niż wyniki eksperymentalne, uzyskano dla spoiny złączy blach o grubości $50 \mathrm{~mm}$ stali YP360 badanych $w$ temperaturze $t=-36^{\circ} \mathrm{C}($ tabl. II). Złącza spawane dwustronnie (ukosowanie $X$ ) wykonano przy użyciu drutu SF-3AM - tego samego jak w poprzedniej serii badań dla $\mathrm{t}=-60^{\circ} \mathrm{C}$.

Ponadto przeprowadzono badania własne oraz wykorzystano dane zawarte w pracy [3] dotyczące złączy spawanych dwustronnie (ukosowanie X) wykonanych ze stali 18G2ANb, której obecnie odpowiednikiem jest stal E420. Podstawowe właściwości mechaniczne tej stali wyznaczone na próbkach kontroInych były wysokie i wynosiły: $R_{e}=455 \mathrm{MPa}, R_{m}=608 \mathrm{MPa}$, $K V=119,2 \mathrm{~J}, A_{5}=28 \%$. Złącza z blachy o grubości $30 \mathrm{~mm}$ wykonano metodą spawania łukowego przy użyciu zasadowych elektrod otulonych EB 1.50. Wyniki badań przedstawiono w tablicy III. Badania wykazały, że wartości krytyczne CTOD obliczone ze wzoru (8) dla materiału rodzimego w temp. $\mathrm{t}=20^{\circ} \mathrm{C} \mathrm{it}=-4^{\circ} \mathrm{C}$ były bardzo bliskie wynikom tego parametru wyznaczonym eksperymentalnie (tabl. III). Związane to jest niewątpliwie $z$ właściwościami materiału rodzimego $\left(R_{e} / R_{m}=0,748\right)$, który zachowuje się zgodnie z modelem materiału sprężysto-plastycznego z umocnieniem.

Podobnie zbliżone wartości obliczeń i badań CTOD uzyskano dla spoiny tych złączy w $\mathrm{t}=-4{ }^{\circ} \mathrm{C}$, ale wartość CTOD obliczona ze wzoru (8) była wyraźnie wyższa niż wynik uzyskany z eksperymentu $(B=24 \%)$. Związane to może być $z$ pojawieniem się $w$ tej temperaturze cech kruchego wzrostu pęknięcia (rys. 4b), podczas gdy w materiale rodzimym dominował plastyczny wzrost pęknięcia (rys. 4a). Stwierdzono to na przełomach próbek przy badaniu CTOD w tych strefach złącza (rys. 4).

W temp. $+20{ }^{\circ} \mathrm{C}$ w obu strefach złącza wartości CTOD były wyższe niż w temp. $-4{ }^{\circ} \mathrm{C}$, ponieważ wzrost pęknięcia w materiale rodzimym miał charakter plastyczny (rys. 4a), a w spoinie dominowały również cechy pękania plastycznego (rys. 4b).

Kolejny materiał, który badano to stal S355 (dawna stal 18G2A). Wyniki badań i obliczeń przedstawiono w tablicy IV. Złącza spawane łukowo dwustronnie (ukosowanie X) a) $\delta_{c}$

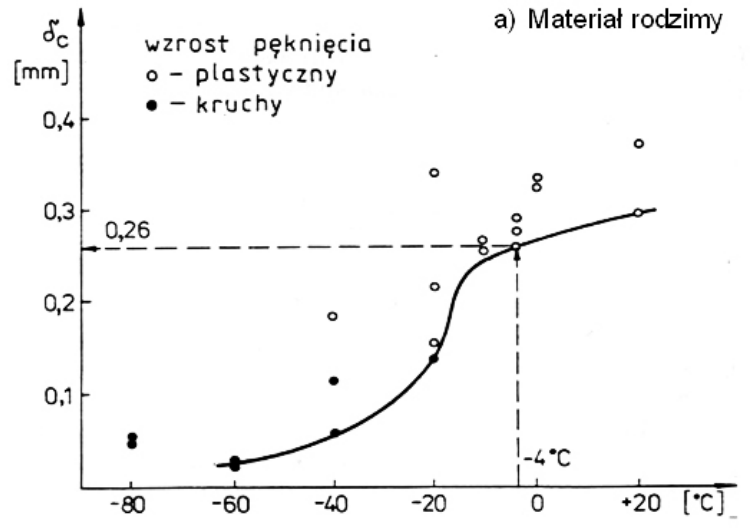

b)

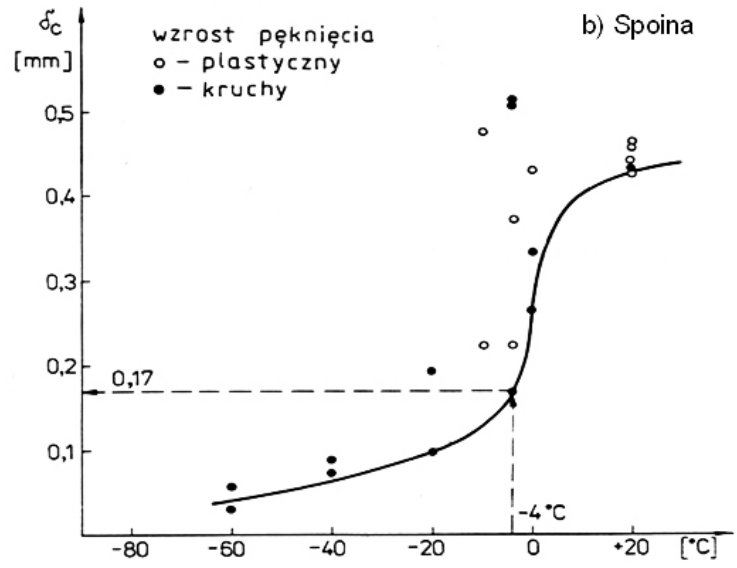

Rys. 4. Wpływ temperatury na wartość krytyczną rozwarcia czoła pęknięcia CTOD oraz na wzrost pęknięcia w materiale rodzimym (a) i w spoinie (b) złącza spawanego wykonanego ze stali 18G2ANb (E420) przy użyciu elektrod EB 1.50 [3]

Fig. 4. Influence of temperature on the critical value of crack tip opening displacement CTOD and on crack growth in original material (a) and in weld (b) of the welded joint made from 18G2ANb steel (E420) use the electrodes EB 1.50 [3]

z blachy o grubości $12 \mathrm{~mm}$ wykonano przy użyciu tych samych elektrod otulonych jak dla stali E420. Materiał rodzimy miał cechy materiału sprężysto-plastycznego z umocnieniem $\left(R_{e} / R_{m}=0,639\right)$. Wartości CTOD obliczone wg wzoru (8) i wyznaczone eksperymentalnie dla tej stali były zbliżone. Natomiast w spoinie ze względu na dominację cech pękania plastycznego $\left(R_{e} / R_{m}=0,920\right)$ wyniki obliczeń CTOD wg wzoru (8) były wyraźnie niższe niż uzyskane eksperymentalnie.

Tablica III. Właściwości złączy ze stali 18G2ANb (E420) spawanych zasadowymi elektrodami otulonymi EB 1.50 Table III. Mechanical proprieties of welded joints from 18G2ANb steel (E420) made using the basic coated electrodes EB 1.50

\begin{tabular}{|c|c|c|c|c|c|c|c|c|}
\hline $\mathrm{t}\left[{ }^{\circ} \mathrm{C}\right]$ & Strefa złącza & $R_{e}[\mathrm{MPa}]$ & $\mathbf{R}_{\mathrm{m}}[\mathrm{MPa}]$ & $R_{e} / R_{m}[-]$ & $\mathrm{KV}[\mathrm{J}]$ & $\mathrm{CTOD}_{\text {exp. }}[\mathrm{mm}]$ & $\mathrm{CTOD}_{\mathrm{wz} .(8)}[\mathrm{mm}]$ & Błąd B [\%] \\
\hline \multirow{2}{*}{20} & Materiał rodzimy & 455 & 608 & 0,748 & 126 & 0,298 & 0,301 & 1 \\
\hline & Spoina & 520 & 570 & 0,912 & 150 & 0,427 & 0,361 & -15 \\
\hline \multirow{2}{*}{-4} & Materiał rodzimy & 460 & 610 & 0,754 & 110 & 0,260 & 0,265 & 2 \\
\hline & Spoina & 525 & 585 & 0,897 & 88 & 0,170 & 0,211 & 24 \\
\hline
\end{tabular}


Tablica IV. Właściwości mechaniczne złączy spawanych ze stali S355 przy użyciu zasadowych elektrod otulonych EB 1.50 Table IV. Mechanical proprieties of welded joints from S355 steel made using the basic coated electrodes EB 1.50

\begin{tabular}{|c|c|c|c|c|c|c|c|c|}
\hline $\mathbf{t}\left[{ }^{\circ} \mathbf{C}\right]$ & Strefa złącza & $\mathbf{R}_{\mathbf{e}}[\mathrm{MPa}]$ & $\mathbf{R}_{\mathbf{m}}[\mathrm{MPa}]$ & $\mathbf{R}_{\mathrm{e}} / \mathbf{R}_{\mathbf{m}}[-]$ & $\mathbf{K V}[\mathbf{J}]$ & $\mathbf{C T O D}_{\text {exp. }}[\mathbf{m m}]$ & $\mathbf{C T O D}_{\text {wz.(8) }}[\mathbf{m m}]$ & $\mathbf{B}$ łąd B [\%] \\
\hline \multirow{2}{*}{20} & Materiał rodzimy & 365 & 571 & 0,639 & 140 & 0.302 & 0,336 & 11 \\
\cline { 2 - 10 } & Spoina & 520 & 565 & 0,920 & 116 & 0.395 & 0,279 & -39 \\
\hline
\end{tabular}

Podobnie jak przy eksperymentalnym wyznaczeniu wartości CTOD tak i przy wyznaczaniu odporności na pękanie $K_{\mathrm{Ic}}$ należy liczyć się z trudnościami wynikającymi z wymogów przygotowania próbek oraz stosowania odpowiedniej procedury badań. Dlatego autorzy podjęli się oceny możliwości zastosowania wzorów: (4) $\div$ (7) opisujących korelację między odpornością na pękanie $\mathrm{K}_{\mathrm{lc}}$ a pracą udarowego zginania $\mathrm{KV}$. Wzór określający $\mathrm{K}_{\mathrm{lc}}$ na podstawie właściwości mechanicznych materiału takich jak: granica plastyczności $R_{e}$, moduł sprężystości podłużnej E oraz krytyczna wartość rozwarcia pęknięcia na czole szczeliny $\delta_{\mathrm{lc}}$ albo krytyczna wartość całki $J_{I c}$ to znana z literatury [1] zależność:

$$
K_{I c}=\sqrt{\left(R_{e} \cdot \delta_{c} \cdot E\right)}=\sqrt{\left(J_{l c} \cdot E\right)} .
$$

Do praktycznej oceny odporności na pękanie stosowane są niekiedy inne zależności - np. zależność określająca wymaganą odporność na pękanie $\mathrm{K}_{\mathrm{lr}}$, która stosowana jest na Słowacji zgodnie z normą [13] w postaci:

$$
\mathrm{K}_{\mathrm{Ir}}=\mathrm{R}_{\mathrm{eg}} \cdot \sqrt{\pi \cdot 0,001 \cdot \mathrm{a}_{\mathrm{F}} \cdot \mathrm{k}_{\mathrm{c}} \cdot\left(2 \mathrm{k}_{\mathrm{s}}-1\right)}[\mathrm{MPa} \mathrm{Vm}](13)
$$

gdzie:

$\mathrm{R}_{\mathrm{eg}}$ - granica plastyczności blachy o grubości g (w mm),

$a_{F}=0,2 g-$ normatywna max. wielkość szczeliny, pęknięcia lub wady (zakres $5 \div 20 \mathrm{~mm}$ ),

$\mathrm{k}_{\mathrm{c}}=1,5, \mathrm{k}_{\mathrm{s}}=2-$ współczynniki.

Autorzy pracy dokonali porównania wartości $\mathrm{K}_{\mathrm{lc}}$ obliczonych wg różnych wzorów korelacyjnych i ich zgodności z wymaganą odpornością na pękanie $K_{\mathrm{lr}}$, wyznaczoną zgodnie z ujętą w normie zależnością (13).

W tym celu przedstawiono przykładowe wyniki obliczeń tych wielkości dla trzech gatunków drobnoziarnistych stali spawalnych S355, S420, S460. Stale te w formie blach były normalizowane po obróbce, tj. po ulepszeniu cieplno-mechanicznym (walcowaniu). Blachy miały różne grubości g w przedziale $\mathrm{g}=25 \div 80 \mathrm{~mm}$ i $w$ związku z tym różne wartości granicy plastyczności $R_{\text {eg }}$ (malejące ze wzrostem grubości): $R_{\text {eg }}=345 \div 325 \mathrm{MPa}$ dla stali $S 355, R_{\mathrm{eg}}=400 \div 380 \mathrm{MPa}$ dla stali S420 i $R_{\text {eg }}=440 \div 410 \mathrm{MPa}$ dla stali S460. Są to stale wykazujące cechy zgodne $z$ modelem materiału sprężystoplastycznego $z$ umocnieniem $\left(R_{e} / R_{m}<0,9\right)$. Wymienione stale stosowane są na elementy konstrukcyjne - np. na przęsła mostów drogowych.

Najlepszą zgodność wyników obliczeń wartości K $\mathrm{Ic}$ z zależnością określającą K $\mathrm{K}_{\mathrm{Ir}}$ (wz. 13) uzyskano dla wzoru (5), co przedstawiono na rysunku 5 . Dodatkowo wartości $K_{\mathrm{lc}}$ wyznaczone wg tego wzoru są niższe niż $K_{\mathrm{r}}$, co zwiększa stan bezpieczeństwa elementu konstrukcyjnego.

Jednak jeszcze niższe wyniki obliczeń $K_{\mathrm{Ic}}$ uzyskuje się stosując wzór (6), co przedstawiono na rysunku 6, ale ich

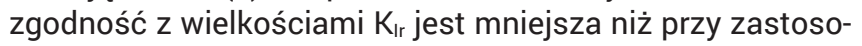
waniu wzoru (5).

Natomiast wyniki obliczeń ze wzoru (6) są bardzo bliskie wynikom uzyskanym z klasycznej zależności (12), do której podstawiono wartości $\delta_{\mathrm{lc}}$ wyznaczone na podstawie rozwarcia pęknięcia KV wg wzoru (8). Widać to bardzo wyraźnie na rysunku 7 (zwłaszcza w stalach $\$ 420$ i S460). Wzrosty wartości $K_{\mathrm{lc}}$ i $\mathrm{K}_{\mathrm{lr}}$ wraz ze zwiększaniem grubości blach, przedstawione na rysunkach $4 \div 7$, aproksymowano funkcjami logarytmicznymi o wysokich współczynnikach korelacji.
W prezentowanym artykule nie zamieszczono wykresów dla wartości $K_{\mathrm{Ic}}$ wyznaczonych ze wzoru (4) i (7). Wyniki te w przypadku wzoru (4) są mocno zawyżone w stosunku do wartości K Ir wyznaczonych ze wzoru (13), a w przypadku wzoru (7) są mocno zaniżone.

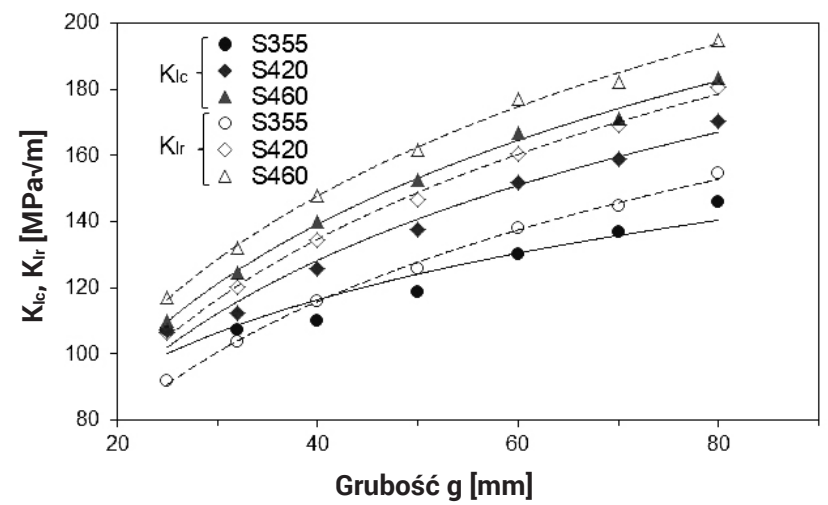

Rys. 5. Odporność na pękanie: $K_{\mathrm{lc}}$ wyznaczana ze wzoru (5) i $\mathrm{K}_{\mathrm{Ir}}$ ze wzoru (13)

Fig. 5. Fracture toughness: $K_{\mathrm{lc}}$ counted from formula (5) and $\mathrm{K}_{\mathrm{l}}$ from formula (13)

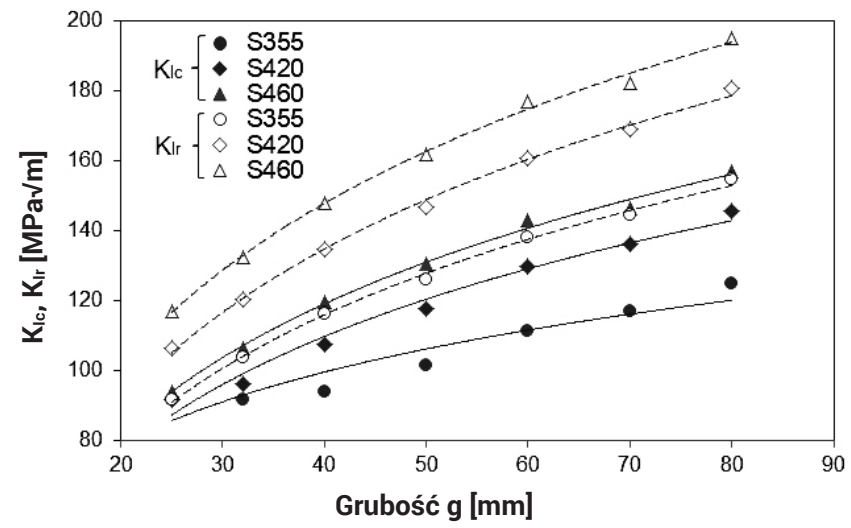

Rys. 6. Odporność na pękanie: $K_{\mathrm{lc}}$ wyznaczana ze wzoru (6) i $K_{\mathrm{lr}}$ ze wzoru (13)

Fig. 6. Fracture toughness: $K_{\mathrm{Ic}}$ counted from formula (6) and $K_{\mathrm{Ir}}$ from formula (13)

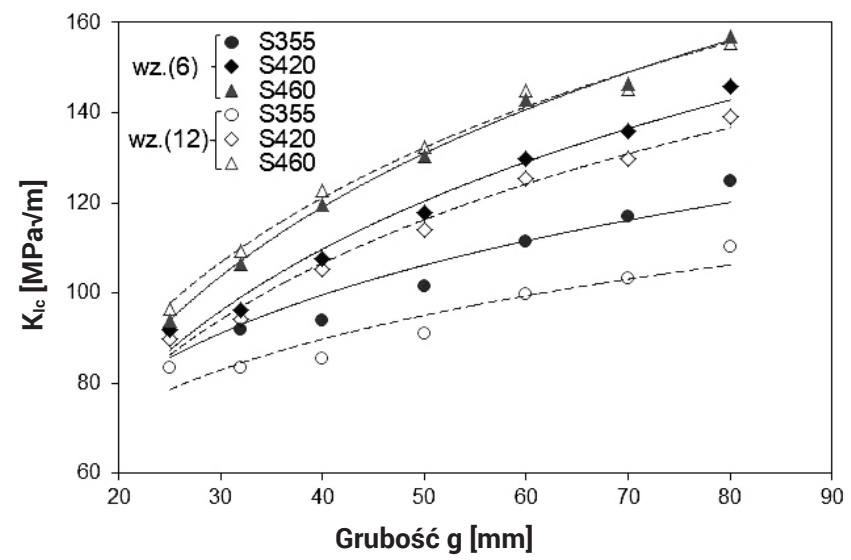

Rys. 7. Odporność na pękanie: $K_{\mathrm{Ic}}$ wyznaczana ze wzoru (6) i ze wzoru (12)

Fig. 7. Fracture toughness: $K_{\mathrm{lc}}$ counted from formula (6) and from formula (12) 


\section{Podsumowanie}

Na podstawie przeprowadzonych badań eksperymentalnych i obliczeń analitycznych wielkości krytycznych określających odporność na pękanie stali i złączy spawanych można stwierdzić, że dla proponowanych wzorów występuje słabsza lub lepsza korelacja wyników obliczeń i badań eksperymentalnych. Zależne jest to zarówno od badanego materiału i spoiny, jak również od budowy wzorów stosowanych do obliczeń inżynierskich.

W przypadku materiału rodzimego i materiału spoiny badanych złączy spawanych o modelu sprężysto-plastycznym $z$ umocnieniem, tj. dla ilorazu $R_{e} / R_{m}<0,9$ zgodność wyników obliczeń krytycznego rozwarcia pęknięcia CTOD na podstawie pracy udarowego zginania KV ich próbek jest dobra. Natomiast dla materiałów o modelu zbliżonym do ciała sprężysto idealnie plastycznego (bez umocnienia) tj. dla $R_{e} / R_{m}>0,9$ zgodność ta jest znacznie gorsza. Wyniki CTOD uzyskane eksperymentalnie w tym przypadku są wyraźnie wyższe niż wyniki obliczeń ze wzoru (8). Tę prawidłowość stwierdzono nie tylko w temperaturze otoczenia $\left(+20^{\circ} \mathrm{C}\right)$, ale także w temperaturach obniżonych.

Wyniki obliczeń wartości $\mathrm{K}_{\mathrm{lc}}$ na podstawie pracy udarowego zginania próbek KV wykazały dobrą zgodność z wymaganą odpornością normową na pękanie $K_{\mathrm{Ir}}$ (wz. 13) w przypadku dwóch wzorów korelacyjnych (wz. 5 i 6). Ponadto wartości obliczone ze wzoru (6) były bardzo bliskie wartościom tego parametru określonego klasyczną zależnością (12) stosowaną w przeliczeniach wartości parametrów odporności na pękanie, tj. $\mathrm{K}_{\mathrm{lc}}, \bar{\delta}_{\mathrm{lc}}$ oraz $\mathrm{J}_{\mathrm{lc}}$.

\section{Literatura}

[1] Kocańda S.: Zmęczeniowe pękanie metali, WNT Warszawa 1985.

[2] Neimitz A.: Mechanika pękania, PWN Warszawa 1998.

[3] Brózda J.: Wprowadzenie do mechaniki pękania, Instytut Spawalnictwa Gliwice 2008.

[4] Rykaluk K.: Pęknięcia w konstrukcjach stalowych, Dolnośląskie Wydawnictwo Edukacyjne Wrocław 2000.

[5] Słania J., Staniszewski K., Hyc K.: Ocena przełomów złączy spawanych po próbie łamania, Przegląd Spawalnictwa 12/2013, s. 142-151.

[6] Stasiuk P., Karolczuk A., Kuczko W.: Rozkład naprężeń w krzyżowym złączu spawanym z uwzględnieniem rzeczywistego kształtu spoiny, Przegląd Spawalnictwa 1/2014, s. 29-33

[7] PN-EN ISO 12737:2006 Metale. Określenie odporności na pękanie w płaskim stanie odkształcenia.
[8] PN-EN ISO 15653:2010 Materiały metalowe - Metoda badania dotycząca wyznaczania quasistatycznej odporności na kruche pękanie spoin.

[9] BS 7448-1:1991 Fracture mechanics toughness tests. Method for determination of Klc, critical CTOD and critical J values of metallic materials.

[10] Blicharski M.: Inżynieria materiałowa, Warszawa, WNT, 2014

[11] Michalak M., Łatka L., Sokołowski P.: Porównanie właściwości mechanicznych powłok natryskiwanych plazmowo proszkowo i z zawiesin, Przegląd Spawalnictwa 10/2017, s. 56-60.

[12] Werner K., Wojsyk K.: Analiza możliwości kruchego pękania spawanych elementów konstrukcji stalowych, Przegląd Spawalnictwa 5/2015, s. 91-93.

[13] STN EN 1993-1-10/NA čl. NB1.1 vzt'ah (1): Material toughness and trough-thickness properties (Eurocode 3: Design of steel structures). 